Abstracta Iranica Abstanica

Revue bibliographique pour le domaine irano-aryen

Volume 40-41 | 2019

Comptes rendus des publications de 2017-2018

\title{
Bruno Jacobs. „Die ikonographische Angleichung von Gott und König in der achämenidischen Kunst"
}

\section{Astrid Nunn}

\section{(2) OpenEdition}

1 Journals

\section{Édition électronique}

URL : http://journals.openedition.org/abstractairanica/49966

DOI : 10.4000/abstractairanica.49966

ISBN : 1961-960X

ISSN : 1961-960X

Éditeur :

CNRS (UMR 7528 Mondes iraniens et indiens), Éditions de l'IFRI

Référence électronique

Astrid Nunn, « Bruno Jacobs. „Die ikonographische Angleichung von Gott und König in der achämenidischen Kunst" », Abstracta Iranica [En ligne], Volume 40-41 | 2019, document 70, mis en ligne le 30 octobre 2019, consulté le 23 avril 2021. URL : http://journals.openedition.org/ abstractairanica/49966 ; DOI : https://doi.org/10.4000/abstractairanica.49966

Ce document a été généré automatiquement le 23 avril 2021.

Tous droits réservés 


\title{
Bruno Jacobs. „Die ikonographische Angleichung von Gott und König in der achämenidischen Kunst"
}

\author{
Astrid Nunn
}

\section{RÉFÉRENCE}

Bruno Jacobs. „Die ikonographische Angleichung von Gott und König in der achämenidischen Kunst“ in Wouter F.M. Henkelman, Céline Redard (eds.). Persian Religion in the Achaemenid Period. Harrassowitz Verlag, Wiesbaden, 2017, p. 247-272 (Classica et Orientalia, vol. 16)

1 L'A. émet l'avis que Ahuramazda n'était pas seulement le dieu du roi et le protecteur de sa royauté, mais aussi l'ancêtre de la dynastie achéménide. En se référant non seulement aux ancêtres mais aussi à Zeus, les épithètes de « paternel » ou « royal » dans les textes classiques le confirment. Quel était le rôle de Achaimenes qui devint le héros éponyme de la dynastie? Les sources écrites suggèrent qu'Achaimenes était le lien entre Ahuramazda et les ancêtres royaux, lien qui finira par en faire l'aïeul de la dynastie. On ne peut vérifier si ce lien a été pensé par Darius ou par un roi le précédant. Quoi qu'il en soit, sur le relief de Bisutun, la figure sortant du disque ailé porte une polos qui fut retravaillé dès l'antiquité. La première version était une tiare à cornes, la seconde une étoile inscrite dans un cercle. Ce dieu ne peut être qu'Ahuramazda. Le fait que la tiare à cornes ait été abandonnée et que le dieu porte désormais une couronne qui, comme celle du roi, est munie d'une étoile inscrite dans un cercle, témoigne d'après l'A. d'un rapprochement iconographique voulu. Celui-ci soulignerait la relation familiale entre dieu et roi et la volonté du roi de se représenter comme une image du dieu. 


\section{AUTEURS}

\section{ASTRID NUNN}

Université de Munich 